\title{
Identification of Pathogenic Bacteria from Diseased Nile Tilapia Oreochromis niloticus with their Sensitivity to Antibiotics
}

\author{
Aishi Hamom, M. M. Mahbub Alam*, Mohammed Mahbub Iqbal, \\ Sarker Mohammed Ibrahim Khalil, Moslima Parven, Tofael Ahmed Sumon \\ and Md. Abdullah-Al-Mamun
}

Department of Fish Health Management, Sylhet Agricultural University, Sylhet, Bangladesh

*Corresponding author

\begin{abstract}
A B S T R A C T
Nile Tilapia (Oreochromis niloticus) is an important aquaculture resource that represents one of the most popular cultured species in the whole world. However, culture of this species face some problems, which are associated with the occurrence of pathogenic bacteria and cause high pecuniary loss. The main aim of this study was to isolate and identify the pathogenic bacteria from diseased farmed O. niloticus and to detect the antibiotic sensitivity with some commonly used antibiotics. Bacteria samples were collected from different parts of the body of both diseased and fresh tilapia and cultured in both nutrient agar and broth media. The bacterial colonies were evaluated using biochemical tests i.e. Gram's staining, Motility test, Carbohydrate fermentation test, Indole test, MR-VP test and Catalase test. The antibiotic sensitivity of the isolated bacteria samples was also detected, using seven antibiotic discs i.e. Ciprofloxacin $(5 \mu \mathrm{g})$, Azithromycin $(15 \mu \mathrm{g})$, Ampicillin $(10 \mu \mathrm{g})$, Tetracycline $(30 \mu \mathrm{g})$, Streptomycin $(30 \mu \mathrm{g})$, Ceftriaxone $(30 \mu \mathrm{g})$ and Erythromycin $(15 \mu \mathrm{g})$. Colony characters and the biochemical analysis revealed the presence of Streptococcus agalactiae, Flavobacterium columnare and Edwardsiella tarda in farmed diseased tilapia, and Aeromonas salmonicida and Streptococcus iniae in healthy tilapia. Based on the density of colonies and clinical signs, the studied tilapia were infected by $S$. agalactiae, causing Streptococcosis. Co-infections in tilapia were occurred by $F$. columnare and E. tarda. Among the antibiotics, tetracycline and ciprofloxacin were more sensitive, azithromycin and streptomycin were moderately sensitive, and ampicillin was resistant to the isolated bacteria. Ciprofloxacin and tetracycline could be used to control the disease in the studied tilapia. The results of the study will be helpful to the farmers for management of bacterial diseases.
\end{abstract}

\section{Keywords}

Bacteria culture, diagnosis, bacterial diseases control, effective antibiotics, aquaculture

Article Info

Accepted:

12 February 2020

Available Online:

10 March 2020

\section{Introduction}

Aquaculture contributes to the production of animal foods of high nutritional value, generating employment and economic income for the world population. Aquaculture is increasingly becoming one of the fastest growing aspect of the agricultural industry worldwide. Fish is a worldwide distributed commodity regarded a cheap source of protein, especially in the developing countries like Bangladesh. It provides a good balance of 
protein, vitamins and minerals. Fishery sector plays a significant role in food security through supplementation of food for developing countries. Fish is an important component of diets around the world. An estimated one billion people rely on fish as their main source of animal protein. The global fish production is estimated as 148.5 million MT per year of which capture fishery accounts for 88.6 million MT and aquaculture 110.2 million MT, and the first sale value estimated at USD 243.5 billion (FAO, 2018). Bangladesh is one of the most suitable countries in the world for freshwater aquaculture, because of its vast resources and favorable agro-climatic conditions. Bangladesh is one of the most leading fish producing country in the world.

The total production was 41.34 lakh MT in 2016-17, where capture fishery (inland open water) contributed 11.63 lakh MT (28.14\%) and culture fishery (inland closed water) contributed 23.33 lakh MT (56.44\%) to total production (DoF, 2018). The growth rates of inland capture fisheries and inland culture fisheries were $11.01 \%$ and $5.89 \%$, respectively. Marine fisheries production was 6.37 lakh MT contributing $15.42 \%$ to total production with growth rate of $1.75 \%$. The fish production has increased more than five times from 7.54 MT in 1983-84 to 41.34 lakh MT in 2016-17 (DoF, 2018). Carps are one of the most important species in aquaculture of Bangladesh. Carp production was estimated as $38 \%$ of the total national fish production followed by Tilapia $10.59 \%$, Pangas $14.59 \%$, koi magur shing and others 33\% (DoF, 2018; Figure 1).

Fisheries sector in Bangladesh play a vital role in providing nutrition, employment, increased GDP growth and foreign exchange earnings. It is one of the main economic sources of our country. Per capita fish intake is about $19.71 \mathrm{~kg}$, supplementing about $60 \%$ of the protein in the daily national diet. The average growth rate last 10 years of Bangladesh was 5.43\% (DoF, 2018). About $11 \%$ of the total population is directly or indirectly employed in fisheries sector (DoF, 2018; FRSS, 2017). The production of aquaculture and capture fisheries of Bangladesh is gradually increasing as the country has a lot of potentiality to utilize haors, baors, lakes, ponds and derelict water bodies for fish production. Fish provides the much needed protein to people living in developing countries at affordable prices. It feeds millions of people daily and lives many through employment in services related to fish and fishery products. The nutritional attributes of fish are high because it is rich in the essential amino acids, has high quality vitamins, and its fatty acids fraction have well established health benefits (Anti-thrombotic activity). The advantages of fish as food are its easy digestibility and high nutritive value. These important attributes make the commodity readily susceptible to microbial attack particularly bacterial pathogen.

Tilapia (O. niloticus) has been recognized as one of the major produced and consumed aquaculture commodity in Asia. The rapidly increasing demand for organic food in the world market has become a consideration in the aquaculture of tilapia. Tilapia are currently known as 'aquatic chicken' due to their high growth rates, adaptability to a wide range of environmental conditions and ability to grow and reproduce in captivity and feed on low trophic levels. Tilapia culture is believed to have originated more than 4000 years ago, but very little information is available on their culture during those ancient times. The trials of tilapia culture were recorded in Kenya in the 1920s. Current food and agriculture organization (FAO) aquaculture production statistics indicates that about 100 countries reported tilapia culture. Asia is the largest tilapia producer in the 
world, $79 \%$ of the production of global farmed tilapia in 2002. Tilapia is mainly farmed in freshwater environment in Asia. Tilapia is grown outside its natural habitat and cultivated worldwide, mainly in countries such as Philippines, Indonesia, Thailand, Malaysia, China, Bangladesh, India, Chile, Mexico, Ecuador, Brazil and Columbia. Among commercial species $O$. Niloticus, $O$. mossambicus, O. Aureus, O. Hornorum, Tilapia rendalli and Tilapia zilli.

The fisheries and aquaculture sector is not without challenges, as in all animal production systems, fish are possibly susceptible to microbial diseases which are one of the major problems hampering production, development and expansion of the aquaculture industry. Changes or deterioration in the aquatic environment cause the occurrence of most fish diseases. Bacteria occur naturally on the skin, in the gut, and in the slime of living fish, even though they cause harm to consumers. There are a few diagnostic laboratories or support services in Bangladesh and all of these laboratories are placed in universities or governmental Research Centers which are far away from rural fish farms. In view of the fact farmers do not understand the signs of diseases and do not report the occurrence of diseases. Laboratory analysis is preferred for the detection of disease and their causing pathogens.

Current knowledge of the health and environmental impact of antibiotics used in aquaculture is poor particularly in developing countries. Drug residues may remain in fish used for human consumption and consequently the antibiotics released into the environment can lead to the development of antibiotic resistant bacteria in the food chain Due to increase in semi-intensive aquaculture systems there is a potential hazard related to the development of antibiotic resistance in the pond micro flora. Resistance to antibacterial agents is a major global public health problem and one that is increasing as these agents continue to lose their effectiveness (Akinbowale et al., 2006). The study was designed to isolate and identify the pathogenic bacteria from Nile tilapia (Oreochromis niloticus) and determine the antibiotic response of the pathogenic bacteria. The objectives of the study were to isolate and identify pathogenic bacteria from diseased farmed Oreochromis niloticus and to determine the sensitivity of the isolated bacteria with commonly used antibiotics.

\section{Materials and Methods}

\section{Study species and period}

The study was performed to isolate and identify bacterial pathogen from Nile tilapia (O. niloticus) with the bacterial sensitivity towards antibiotics during the period of January 2018 to June 2018.

\section{Sample collection}

The diseased and fresh tilapia (O. niloticus) fishes were collected from S B M Agro and Fisheries Ltd., Sylhet, Bangladesh, which is located near the Ratargul Swamp Forest. Both diseased and healthy fishes were collected from two different ponds. Three different sizes of diseased and another three different sizes of healthy fish were selected. Fish samples were transported to the laboratory in a cool box at $-4^{\circ} \mathrm{C}$. Fin, skin, muscle, gill and slime of both diseased and healthy fishes were taken as sampling organ.

\section{Preparation of nutrient agar and nutrient broth media}

Nutrient agar and nutrient broth media were used for the cultivation of microbes supporting growth of a wide range of non- 
fastidious organisms. Nutrient agar medium was prepared by dissolving $28 \mathrm{~g}$ of nutrient agar powder in 1 liter of distilled water following standard methods. The plates containing agar medium were stored in a refrigerator at $4{ }^{\circ} \mathrm{C}$ for further use. Nutrient broth medium was prepared by suspending of $25 \mathrm{~g}$ of nutrient broth powder in 1 liter of distilled following standard methods. The prepared broth medium was stored at refrigerator for further use.

Phenol red sucrose broth was prepared by dissolving $21 \mathrm{~g}$ in 1 liter of distilled water following standard methods. Similarly, lactose broth medium, phenol red maltose broth medium, phenol red mannitol broth medium, glucose broth medium, alkaline peptone water and MR-VP broth medium were prepared by dissolving $13 \mathrm{~g}$ of lactose broth, $21 \mathrm{~g}$ of phenol red maltose broth, $21 \mathrm{~g}$ of phenol red mannitol broth, $20 \mathrm{~g}$ of glucose broth, $30 \mathrm{~g}$ of peptone powder, $17 \mathrm{~g}$ of MR-VP broth powder in 1 liter of distilled water, respectively.

\section{Chemical reagents used in the study}

The reagents used for the study were phosphate buffer saline (PBS), reagents for Gram`s staining (crystal violet, gram`s iodine, acetone alcohol, safranine), 3\% hydrogen peroxide Methylene blue and other common laboratory chemicals and reagents.

The indicator Methyl red (MR) solution was prepared by dissolving 0.1g of Bacto Methyl red (Difco) in $300 \mathrm{ml}$ of $95 \%$ alcohol and diluted to $500 \mathrm{ml}$ by adding $200 \mathrm{ml}$ of distilled water. Potassium hydroxide $(\mathrm{KOH})$ solution was prepared by adding $10 \mathrm{~g}$ of Potassium hydroxide crystal in $100 \mathrm{ml}$ of cold distilled water. Gram Iodine Solution was prepared by dissolving $1 \mathrm{~g}$ of iodine, $2 \mathrm{~g}$ of potassium iodide, and $3 \mathrm{~g}$ of sodium bicarbonate in $300 \mathrm{ml}$ of water. Crystal violet or gentian violet also known as methyl violet 10B or hexamethyl pararosaniline chloride was prepared by dissolving $2 \mathrm{~g}$ crystal violet in $20 \mathrm{ml}$ of $95 \%$ ethyl alcohol in one flask and dissolving $0.8 \mathrm{~g}$ ammonium oxalate monohydrate in $80 \mathrm{ml}$ deionized water in another flask. Acetone was mixed with $95 \%$ of ethanol at 1:1 ratio in an air-tight bottle. The working solution was made by adding 50 $\mathrm{ml}$ acetone with $50 \mathrm{ml}$ ethanol $(95 \%)$ into a bottle. Counter stain (Safranin Solution) was prepared by dissolving 2.5 gram of safranin in $100 \mathrm{ml}$ of $95 \%$ ethanol to make a stock solution. Counterstain solution was obtained by diluting $10 \mathrm{ml}$ of the stock solution with $90 \mathrm{ml}$ of distilled water. Laboratory grade xylene is composed of m-xylene (40-65\%), pxylene $(20 \%)$, o-xylene $(20 \%)$, ethyl benzene $(6-20 \%)$ and traces of toluene, trimethyl benzene, phenol thiophene, pyridine and hydrogen sulfide. The normal saline solution is simply made by adding $0.85 \mathrm{~g}$ of crystalline sodium chloride in $100 \mathrm{ml}$ of cold distilled water. Physiological saline solution (PSS) was prepared by dissolving 8.5 gram of pure Sodium chloride $(\mathrm{NaCl})$ in $1000 \mathrm{ml}$ of distilled water.

\section{Glassware's and other necessary appliances used}

Various type of glassware's and appliances used during the course of the experiment. These are : test tubes (with or without Durham`s fermentation tubes and stopper), petridishes (small, medium and large), conical flask, beaker, pipette $(1 \mathrm{ml}, 10 \mathrm{ml})$, hanging drop slides, glass road spreader, test tube stand, blender machine, water bath, incubator, refrigerator, freeze, thermometer, sterilizing instruments, Platinum loop, hot air oven, electronic balance, compound microscope, slides, cover slips, Laminar air flow, autoclave machine, distilled water plant, digital camera, jar, sterilized cotton, immersion oil, beaker, hand gloves, spirit 
lamps, bacteriological loop, glass spreader and forceps, scissors et.

\section{Preparation of sample for bacterial culture}

At first, both the diseased and fresh fishes were sacrificed to collect the sub-sample (Fig 2). For this purpose, several sterile cotton buds were used and sterile inoculating loop were taken to collect slime and mucus from the whole skin of fishes, gills, fins, and skin and muscle of the both infected and fresh fishes. After that, the cotton buds containing sample were taken to the sterile nutrient agar media in zigzag method and inoculated into the nutrient broth with the help of sterile inoculating loop. Both nutrient agar media and the nutrient broth media were incubated at $37^{\circ} \mathrm{C}$ for 24 hours in incubator until different bacterial colonies were appeared. A clear, distinct and good quality colony from each plate was then picked with the help of sterile inoculating loop onto the agar media that was prepared before inoculation. Culturing into sub-culture plate was done with a view to obtaining a pure culture of growth (Fig.3-5). The plates were incubated at the temperature of $37^{\circ} \mathrm{C}$ for 24 hours in incubator. The whole inoculating process was done in the laminar air flow to avoid growth of unwanted microorganisms.

\section{Identification of bacterial isolates}

Identification of tentative bacterial cultures was performed on the basis of colony morphology and biochemical tests including grams staining, motility test, indole test, MRVP test, carbohydrate fermentation test and catalase test.

\section{Colony characteristics}

Pathogens were preliminary identified based on morphological characteristics such as size, shape, color, texture, form, opacity developed after 24 hours of incubation at $37^{\circ} \mathrm{C}$ temperature.

\section{Gram staining}

Gram staining of pure culture was done by taking a small sample from broth culture with a sterile bacteriological loop and spread over the slide. Fixing was done by gentle heat of slide with burner until dry. Staining was done by applying crystal violet on each of smear for two minutes, washed with running tape water and kept air dye the smears. Few drops of gram's iodine was then added on the smear for 1 minute, washed in running tape water and then kept air dye for few seconds. Decolorizing agent acetone-alcohol was used to decolorize the smears for about 15-20 seconds, followed immediately with a water wash. Safranin was used as contrasting staining for 15 seconds, followed immediately with a water wash, blotted and allowed to dry. Direct observation under light microscope (100X) using immersion oil, continued where Gram (+) bacteria showed a purple color and Gram (-) bacteria a pink or red color.

\section{Motility test}

Presence of bacterial flagella is obtained by observing motility. Hanging drop technique is usually used to observe the mobility of live unstrained bacteria. In other method, bacteria are inoculated into a semi-solid agar medium, migrate from the inoculation site and for a characteristic pattern of growth, which indicates mobility. In this current study, motility test was done by using hanging drop method.

\section{Carbohydrate fermentation test}

Carbohydrate fermentation tests detects the ability of microorganisms to ferment a specific carbohydrate. In fermentation process, an organic substrate serves as the 
final electron acceptor. The final product of carbohydrate fermentation is an acid or acid with gas production. Common final product of bacterial fermentation includes lactic acid, formic acid, acetic acid, butyric acid, butyl alcohol, acetone, ethyl alcohol, carbon dioxide, and hydrogen. Fermentation reactions are identified by the color change of a $\mathrm{pH}$ indicator when acid products are formed. Phenol red is commonly used as $\mathrm{pH}$ indicator in carbohydrate fermentation tests. Other $\mathrm{pH}$ indicators such as bromocresol purple, bromomethyl blue also use in this test. Durham tubes are used to detect gas production. These small, slender test tubes (6 by $50 \mathrm{~mm}$ ) are inserted upside down inside larger $(13$ by $100 \mathrm{~mm})$ test tubes. These tubes become filled with gas after sterilization. If gas is produced an air bubble is visible into test tube.

Firstly, broth medium was prepared by mixing all ingredients in distilled water. Five different type of carbohydrates (glucose, sucrose, lactose, maltose, mannitol) was selected for each batch of broth medium. 3.5 $\mathrm{ml}$ of $1 \%$ of peptone water and $1.5 \%$ of sugar solution was used in each of test tube and the Durham tubes were inserted into test tubes in inverted condition. Media was sterile by autoclaving for 15 minutes at $121^{\circ} \mathrm{C}$ with 15 pounds of pressure and allow them to cool at room temperature after sterilization. Each test tube was inoculated with 5-6 drops of the test microorganisms using a sterile inoculating loop and swirled gently to mix the content. Then add 2-3 drops of 1\% bromocresol purple or phenol red as an indicator into each of test tube. Tubes were incubated at $37^{\circ} \mathrm{C}$ for $48-72$ hours. Results were recorded on the basis of color development. A yellow color indicated that enough acid production occurs and bubble trapped within the Durham tube indicated gas production. A delayed fermentation results an orange color and no bubble in Durham tubes indicated that anaerobic organisms.

\section{Indole test}

All proteins contain the amino acid tryptophan. Bacteria that contain the enzyme tryptophanase can hydrolyze tryptophan to its metabolic products such as indole, pyruvic acid, and ammonia. Bacteria use the pyruvic acid and ammonia for their metabolism process, indole is not used and accumulates in the medium. Some bacteria can produce indole from amino acid tryptophan using the enzyme tryptophanase. Production of indole is detected using Ehrlich reagent or Kovacs reagent. The formation of deep red color in the reagent layer after gentle agitation indicated positive indole test. For indole test, firstly broth medium was prepared by mixing all the components. Inoculation of test microorganisms was done by using a sterile inoculating loop. Then, the broth medium was allowed to incubate at $37^{\circ} \mathrm{C}$ for 48 hours. After incubation mix $5 \mathrm{ml}$ of broth culture and $1 \mathrm{ml}$ of xylene solution and allow them into a vortex mixture to mix properly. Then $0.5 \mathrm{ml}$ of Kovacs reagent was used and wait for 1-2 minutes until color will change. A pink color ring was formed at the top of the solution that indicate positive indole test and in negative cases, there was no color change.

\section{Methyl red (MR) and Voges- Proskauer (VP) test}

Methyl red (MR) test is done to detect the ability of an organism to produce and maintain stable acid end products from glucose fermentation. Some bacteria produce large amount of acid from glucose fermentation because they overcome the buffering action of the system. Methyl red is a $\mathrm{pH}$ indicator which remains red in color at $\mathrm{pH}$ of 4.4 or less. Voges- Proskauer (VP) test is used to detect bacteria that ferment glucose, leading to 2,3-butanediol accumulation in the 
medium. Adding 40\% $\mathrm{KOH}$ and a 5\% solution in absolute ethanol detects the presence of acetoin, that synthesize 2,3butanediol. Reagents and acetoin reaction produce a cherry-red color in the culture medium indicates positive VP test and absence of red color indicates negative VP test.

\section{Catalase test}

Organisms must trust on defense mechanism that help them to repair or escape the oxidative damage of hydrogen peroxide. Some bacteria produce the enzyme catalase which helps in cellular detoxification. Catalase enzyme neutralizes the bacterial effects of hydrogen peroxide and breakdown the hydrogen peroxide into water and oxygen. Catalase positive test shows the rapid production of bubbles and the absence of bubble indicates negative reactions.

\section{Antibiotic sensitivity test}

The procedure of the sensitivity test was followed simply that a filter disks filled with an antibiotic (Table 1) applied to the surface of an nutrient agar plate which contain the microorganism to be tested and the plate is incubated at $37^{\circ} \mathrm{C}$ for $24-48$ hours. Each of disks is placed at some particular distances and the effectiveness of a particular antibiotic is shown by the presence of growth-inhibition zones. These zones of inhibition (ZOIs) appear as clear ring form surrounding the disk from which the substances with antimicrobial activity diffused. The diameter of the ZOI can be measured with a ruler or a sliding caliper. The result of measured zone diameter can be compared with a standard chart to obtain susceptible ( $\mathrm{S}$ ) and resistant $(\mathrm{R})$ values. There is also a zone of intermediate resistance (I) which indicates that the antibiotic may not sufficient enough to eliminate the microorganisms from the body. Sensitive (S) zone inhibition is wider than or equal to 18 $\mathrm{mm}$, intermediate (I) zone inhibition between 13-17 $\mathrm{mm}$ and resistant (R) zone of inhibition or less than $13 \mathrm{~mm}$.

\section{Results and Discussion}

The materials and methods described in the previous chapter delivers the baseline of identification of bacterial pathogen from diseased Oreochromis niloticus with their sensitivity to antibiotics. Based on the clinical morphology, biochemical characteristics of different bacteria the identified bacteria were: Streptococcus iniae, Streptococcus agalactiae, Edwardsiella tarda, Flavobacterium columnare, Aeromonas salmonicida. These pathogenic bacteria were cultured in nutrient agar first and appears round, smooth, different in color, dewdrop like colonies on the petridishes after incubation. After 24 hours' incubation, turbidity and heavy sedimentation on nutrient broth was observed.

The well grown, good cultures were subjected to biochemical tests and were tabulated in the table. In this study, the aim was to grow the cultures which withstand for prolonged subculture and those sub-cultures were subjected to biochemical tests. For any biochemical tests, the bacterial culture should be long survival culture.in this study, some kinds of biochemical tests were done to identify the absolute pathogenic bacteria and these are Gram staining, Carbohydrate tests, Indole test, Catalase test, MR-VP test, and Motility test. After biochemical tests of some good cultures, some positive and negative results were observed and based on colony morphology, cultures were subjected to antibiotic sensitivity test. The antibiogram profile was done by culturing bacteria on nutrient agar using some particular commercially available antibiotic with distinct concentration. The results, according 
to the diameter of ring form provided that most of bacteria showed highly sensitive, intermediate, and some were resistant to those antibiotics.

\section{Clinical pathology of Tilapia (O. niloticus)}

External analysis showed cynical signs of disease caused by pathogenic bacteria. Signs commonly found are related to bleeding skin, lesion on the skin, less amount of slime, body depigmentation, frayed fins, fin erosions, distended gallbladder, liver discoloration, body ulceration, corneal opacity and secondary infection appeared on the body (Figure 1).

\section{Isolation of pathogenic bacteria}

Nutrient agar and nutrient broth were used to grow the pathogenic bacteria and in both medium bacteria started grow diversely producing dense or thin, round or irregular shape, smooth, color or colorless colonies after incubation for 24 hours. Nutrient broth was also a good medium of bacterial culture. Culture of bacteria in nutrient broth produce a turbid and heavy sedimentation into the test tube after incubation period. The good colonies were subjected to the sub-culture and further pure culture in separate medium used for the growth of $S$. iniae, S. agalactiae, $E$. tarda, F.columnare, A. salmonicida.

\section{Identification of pathogenic bacteria from O. niloticus}

On the basis of morphological characteristics and cultural characteristics five (5) different pathogenic bacteria are identified from diseased and healthy tilapia (Oreochromis niloticus) and the identified bacteria are Streptococcus iniae, Streptococcus agalactiae, Edawrdsiella tarda, Flavobacterium columnare, Aeromonas salmonicida.

\section{Identification of bacterial colonies}

Identification of pathogenic bacteria from Oreochromis niloticus was done by colony characteristics, biochemical tests (Gram staining, Indole test, Carbohydrate fermentation test, MR-VP test, Catalase test, motility test).

Colony characteristics of $S$. iniae, $S$. agalactiae, $F$. columnare, $E$. tarda, $A$. salmonicida

The colony characteristics of $S$. iniae, $S$. agalactiae, $F$. columnare, $E$. tarda, $A$. salmonicida were examined by the observation of cultured bacterial colony colors, shape, size and transparency (Table.3; Fig.6-10).

\section{Gram's staining}

Results of gram staining are shown in Table. 3 and Fig.11-15.

Motility test of $S$. iniae, $S$. agalactiae, $F$. columnare, E. tarda, A. salmonicida

E. tarda and $F$. columnare were found motile whereas $S$. iniae, $S$. agalactiae and $A$. salmonicida were found non-motile in hanging drop slide (Fig.16-20).

\section{Carbohydrate fermentation tests}

Five (5) commercially available sugar such as glucose, lactose, sucrose, maltose, and mannitol were used for carbohydrate fermentation tests. Acid and gas production were indicated by the change of color from red to yellow and presence of gas bubbles into the Durham's tubes (Table.4; Fig.21-28).

\section{Biochemical tests}

The results of Biochemical tests are shown in Table-5 and Fig.29-41. 


\section{Antibiotic sensitivity test}

The isolated bacterial colonies were tested against seven commercially available antibiotics and the results of their sensitivity are presented in Table.6-7. Among them, most of the bacterial pathogen were sensitive against Ciprofloxacin (100\%) and Tetracycline (100\%), intermediate to Erythromycin (20\%), Azithromycin (20\%), Streptomycin $(40 \%)$, and resistance against Ceftriaxone (60\%), Ampicillin (100\%). Where Ciprofloxacin (100\%) and Tetracycline $(100 \%)$ were found more sensitive to all of the identified colonies and Azithromycin, Streptomycin, Erythromycin were intermediate to all isolates bacteria. (Fig.42-46).

Bangladesh is one of the most suitable country for fisheries in the world, having the world's largest flooded wetland and the third largest aquatic biodiversity in Asia after China and India. Tilapia has several positive attributes than other commercial fish species. Due to consumer's popularity, tilapia has world's second most important cultured fish after carp. Most Tilapias (O. niloticus) are produced under polyculture in extensive and semi-intensive culture by farmers and faces different types of problems like diseases caused by bacteria, virus, parasites and fungal pathogens which results high mortality of $O$. niloticus.

The study showed that the presence of pathogenic bacteria is not only in the infected fish but also in healthy fish sample. Colony characters and the biochemical analysis revealed the presence of $S$. agalactiae, $F$. columnare and E. tarda in farmed diseased tilapia, and A. salmonicida and S. iniae in healthy tilapia. Based on the density of colonies and clinical signs, the studied tilapia were infected by $S$. agalactiae, causing Streptococcosis. Co-infections in tilapia were occurred by $F$. columnare and E. tarda. Many authors isolated and identified pathogenic bacteria from various fish samples (Sugita et al., 1985; Dodson et al., 1999; Sarker et al., 2000; Al-Harbi and Uddin, 2003; Sabur, 2006; Klesius et al., 2008; Saeed, 2010; Amal and Zamri, 2011; Adebayo-Tayo et al., 2012; Sankar et al., 2012; Saikot et al., 2013; Anshary et al., 2014; Nilla, 2014; Monir et al., 2017; Parven, 2018; Goni et al., 2020). Goni et al., (2020) isolated four pathogenic bacteria such as Aeromonas hydrophila, Flavobacterium columnare, Edwardsiella tarda and Pseudomonas sp. from diseased Shing (H. fossilis). Parven (2018) isolated and identified three pathogenic bacteria such as Aeromonas hydrophila, Edwardsiella ictaluri and Pseudomonas sp. diseased Pangasius hypophthalmus, and E. ictaluri was identified as the causative agent for the disease, Bacillary Necrosis.

External analysis showed the clinical signs of disease such as skin hemorrhages, corneal opacity, skin lesion, less mucus secretion, body ulceration, liver discoloration, frayed fins and intestine and vesicle inflammation, these abnormalities are considered as the main symptoms of infection reported by Giordano et al., (2010) observed signs such as exophthalmia, anorexia, skin alterations, corneal opacity, bleeding and extension of the visceral cavity was similar as the present study.

Soto (2009) reported that the bacteria are the cause of epithelial hyperplasia in gills and necrosis in the internal organs, mainly in spleen, heart, liver and kidney. For example, Yardimci et al., (2011) indicate that genus Aeromonas sp.is associated with hemorrhages in gills and skin, weakness and anorexia as well as vison loss by breaking orbital eyes, the above results were much similar reported by Claviio, who reported that the presence of genus Edwardsiella sp., causes septicemia in 
internal and external organs, including liver, kidney, spleen, skin, rectum, fins, abdominal inflammations and opaque eye. Bacteria which are gram negative are the main cause of bacterial disease, for example Austin et al., (2016), mention that genus Aeromonas sp. causes furuncolosis and hemorrhagic septicemia in skin.

Asencios et al., 2014; conducted a study in Asia and Latin America, were isolated near 500 cases of Streptococcus sp. coming from tilapia ( $O$. niloticus), which $82 \%$ of prevalence were isolates of $S$. agalactiae and $18 \%$ of S. iniae in the Oreochromis sp. some authors mention that $S$. agalactiae is among the, most prevalent species in Latin American countries. In Brazil and Columbia, this bacterial infection has caused high mortality in tilapia farms.

This study was first identified by PCR $S$. agalactiae in naturally infected tilapia from nursery and grow-out phases in Piura, Peru, and to characterize histopathological lesions caused by this bacterium. The correlation between the histopathological findings with the PCR can provide greater support in relation to the diagnostic and specific treatment for the diseases.

Clinical signs observed in the fish samples experimentally identified with $S$. Iniae and $S$. agalactiae described in literature were similar to those observed in natural infection observed in tilapia experimentally or naturally infected by $S$. iniae (Perera et al., 1994).

Bacterial genera found from the present study, belong to the lineage of species such as S.s iniae, S. agalactiae, E. tarda, F. columnare, A. salmonicida which causes a high risks of fish species especially for tilapia $(O$. niloticus) and also for human health. Burr et al., (2012) considered that the aquatic environment and stress conditions of fish are susceptible to the presence of opportunistic pathogen which cause hemorrhagic septicemia and clinical sign of erratic swimming, uncoordinated movement, bleeding and anorexia.

In this study, antibiotic sensitivity of the identified bacteria $S$. iniae, S. agalactiae, E. tarda, $F$. columnare, A. salmonicida were performed by disk diffusion method against seven (7) different antibiotics, where all of the isolates were found to be sensitive to Ciprofloxacin (100\%) and Tetracycline (100\%), intermediate to Erythromycin (60\%), Azithromycin (80\%), Streptomycin (40\%), and resistance against Ceftriaxone (20\%), Ampicillin (100\%).

Where Ciprofloxacin (100\%) and Tetracycline $(100 \%)$ were found more sensitive to all of the identified colonies and Azithromycin, Streptomycin, Erythromycin were intermediate to all isolates bacteria. Antibiotic resistant patterns were also studied by Dash et al., (2012), Bolarinwa et al., (2011), Ashiru et al., (2011), Tiamiyu et al., (2015), Borty et al., (2016), Khan et al., (2007), Parven (2018) and Goni et al., (2020). Goni et al., (2020) also found Ciprofloxacin $(5 \mu \mathrm{g})$ sensitive to identified bacteria, and

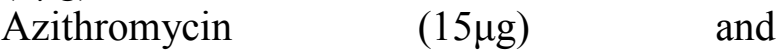

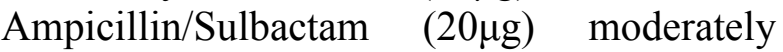
sensitive, but Tetracycline $(30 \mu \mathrm{g})$ and Erythromycin $(15 \mu \mathrm{g})$ resistant to the studied bacteria. Parven (2018) reported that the identified bacteria were $100 \%$ sensitive to Ciprofloxacin $(5 \mu \mathrm{g}), \quad$ intermediate to Azithromycin $(15 \mu \mathrm{g})$ and Tetracycline $(30 \mu \mathrm{g})$, but resistant to Erythromycin $(15 \mu \mathrm{g})$

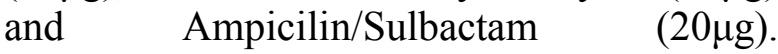
Ciprofloxacin $(5 \mu \mathrm{g})$ was recommended to control bacillary necrosis disease in pangas. 
Table.1 Antibiotics used for sensitivity test

\begin{tabular}{|c|l|c|}
\hline S.No. & \multicolumn{1}{|c|}{ Antibiotics used } & Concentration \\
\hline 1 & Ampicillin & $10 \mu \mathrm{g} / \mathrm{ml}$ \\
\hline 2 & Azithromycin & $15 \mu \mathrm{g} / \mathrm{ml}$ \\
\hline 3 & Streptomycin & $30 \mu \mathrm{g} / \mathrm{ml}$ \\
\hline 4 & Tetracycline & $30 \mu \mathrm{g} / \mathrm{ml}$ \\
\hline 5 & Erythromycin & $15 \mu \mathrm{g} / \mathrm{ml}$ \\
\hline 6 & Ciprofloxacin & $5 \mu \mathrm{g} / \mathrm{ml}$ \\
\hline 7 & Ceftriaxone & $30 \mu \mathrm{g} / \mathrm{ml}$ \\
\hline
\end{tabular}

Table. 2 Colony characteristics of 5 bacterial isolates

\begin{tabular}{|c|l|l|c|}
\hline $\begin{array}{l}\text { Sl. } \\
\text { No. }\end{array}$ & $\begin{array}{c}\text { Name of } \\
\text { bacteria }\end{array}$ & Colony characteristics & Source of bacteria \\
\hline $\mathbf{1}$ & S. iniae & Yellow, sphere shaped and dense colony & Fresh fish \\
\hline $\mathbf{2}$ & A. salmonicida & Yellow colored, round and dense colony & Fresh fish \\
\hline $\mathbf{3}$ & E. tarda & Small, irregular, whitish and dense colony & Diseased fish \\
\hline $\mathbf{4}$ & F. columnare & Yellowish gray, irregular and opaque colony & Diseased fish \\
\hline $\mathbf{5}$ & S. agalactiae & Yellowish, sphere shaped and dense colony & Diseased fish \\
\hline
\end{tabular}

Table.3 Morphology and gram staining properties of $S$. iniae, S. agalactiae, F. columnare, E. tarda, A. salmonicida

\begin{tabular}{|l|c|c|c|}
\hline \multicolumn{1}{|c|}{ Shape } & Characteristics & Identified \\
\hline & provisions & $\begin{array}{c}\text { Gram's } \\
\text { staining } \\
\text { reaction }\end{array}$ & bacteria \\
\hline Round or ovoid shape & Paired or chain varying in length & $+\mathrm{te}$ & $\begin{array}{c}\text { Streptococcus } \\
\text { iniae }\end{array}$ \\
\hline $\begin{array}{l}\text { Straight rods with } \\
\text { rounded ends }\end{array}$ & $\begin{array}{c}\text { Single, paired or } \\
\text { in short chain }\end{array}$ & -ve & A. salmonicida \\
\hline $\begin{array}{l}\text { Small straight rods } \\
\text { rhizoidal edges }\end{array}$ & Single & -ve & E. tarda \\
\hline $\begin{array}{l}\text { Small rods with } \\
\text { rhizoidal edges }\end{array}$ & Single & -ve & F. columnare \\
\hline $\begin{array}{l}\text { Small round with } \\
\text { whitish gray in color }\end{array}$ & Pairs or short \\
chain & +ve & Streptococcus \\
agalactiae
\end{tabular}


Table.4 Results of carbohydrate test of S. iniae, S. agalactiae, F. columnare, E. tarda, A. salmonicida

\begin{tabular}{|r|c|c|c|c|c|}
\hline \multicolumn{7}{|c|}{ Sugar used in carbohydrate fermentation test } & Interpretation of \\
results
\end{tabular}

Table.5 Biochemical properties of S. iniae, S. agalactiae, F. columnare, E. tarda, A. salmonicida

\begin{tabular}{|c|c|c|c|c|c|}
\hline $\begin{array}{c}\text { Indole } \\
\text { test }\end{array}$ & MR test & VP test & Catalase & Motility & $\begin{array}{c}\text { Interpretation of } \\
\text { results }\end{array}$ \\
\hline$+\mathrm{ve}$ & $-\mathrm{ve}$ & $-\mathrm{ve}$ & $-\mathrm{ve}$ & Non-motile & S. iniae \\
\hline$+\mathrm{ve}$ & $-\mathrm{ve}$ & $\mathrm{V}$ & $-\mathrm{ve}$ & Non-motile & S. agalactiae \\
\hline$+\mathrm{ve}$ & $+\mathrm{ve}$ & $-\mathrm{ve}$ & $+\mathrm{ve}$ & motile & E. tarda \\
\hline$+\mathrm{ve}$ & $-\mathrm{ve}$ & $-\mathrm{ve}$ & $+\mathrm{ve}$ & motile & F. columnare \\
\hline -ve & $+\mathrm{ve}$ & $-\mathrm{ve}$ & $+\mathrm{ve}$ & Non-motile & A. salmonicida \\
\hline
\end{tabular}

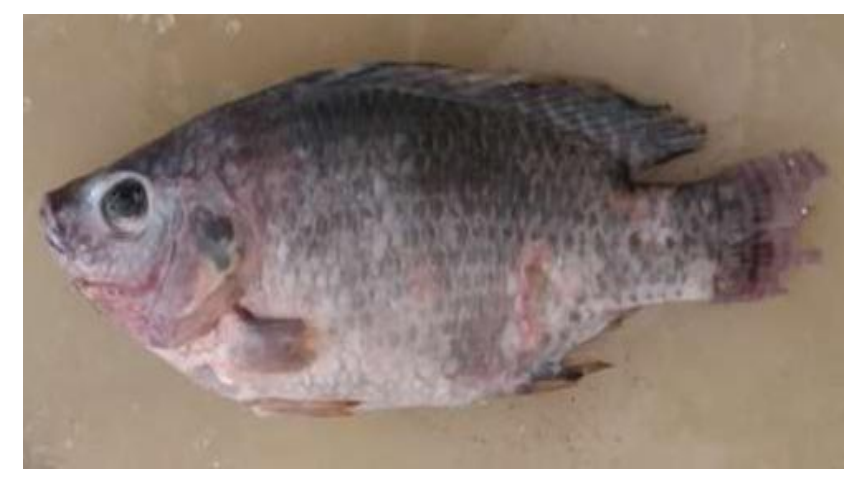

Fig.1 Diseased Nile tilapia Oreochromis niloticus

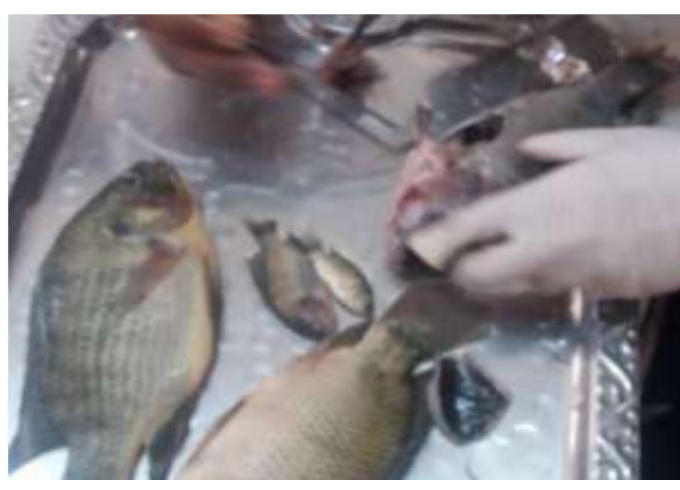

Fig.2 Collection bacterial sample for culture

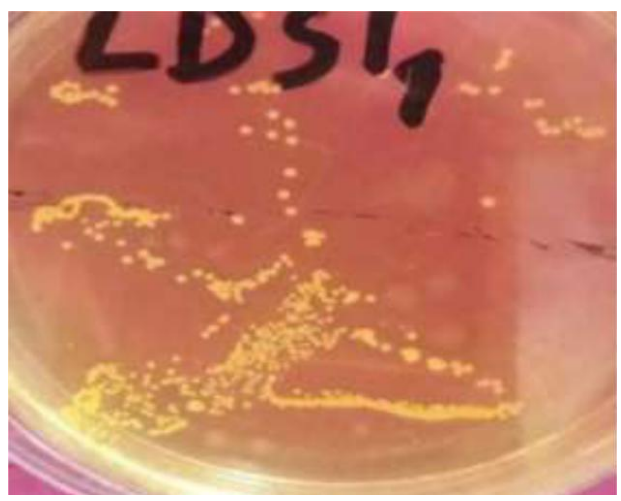

Fig.3 Bacteria culture in nutrient agar medium 


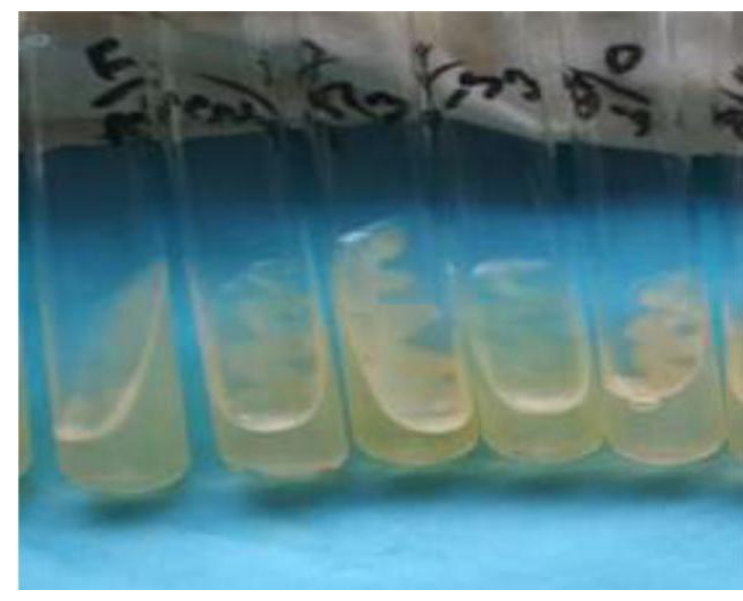

Fig.4 Bacterial colony on Slant

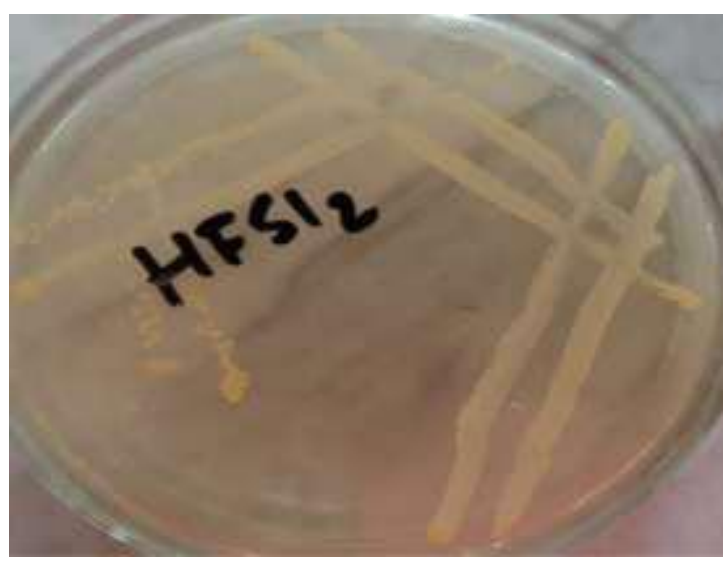

Fig.6 Colony of F. Columnare on plate culture

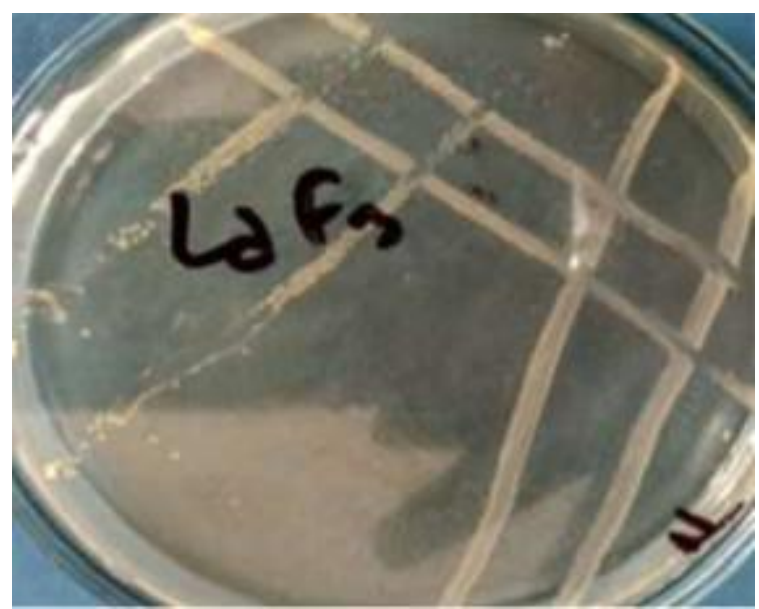

Fig.8 Colony of E. Tarda on plate culture

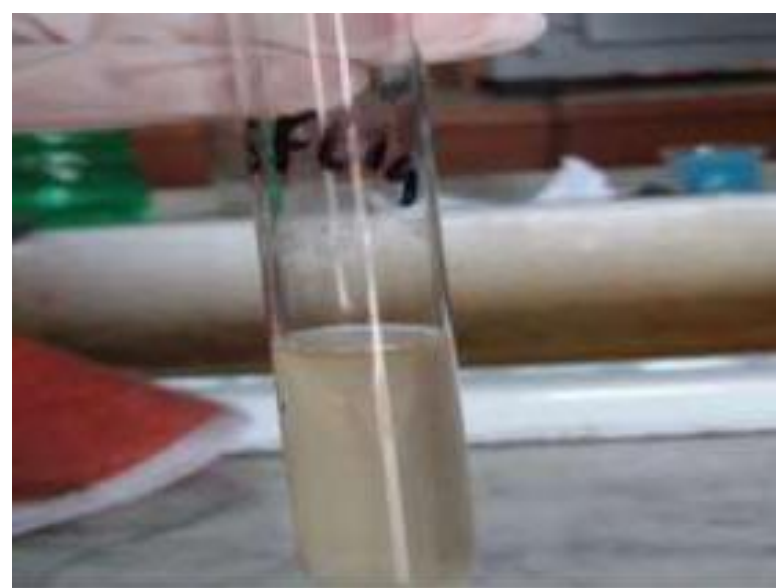

Fig.5 Bacterial colony on broth

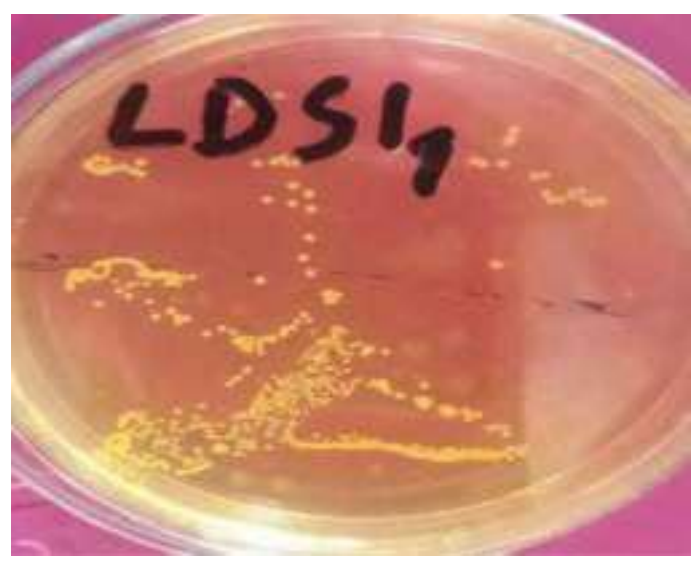

Fig.7 Colony of S. agalactiae on plate culture

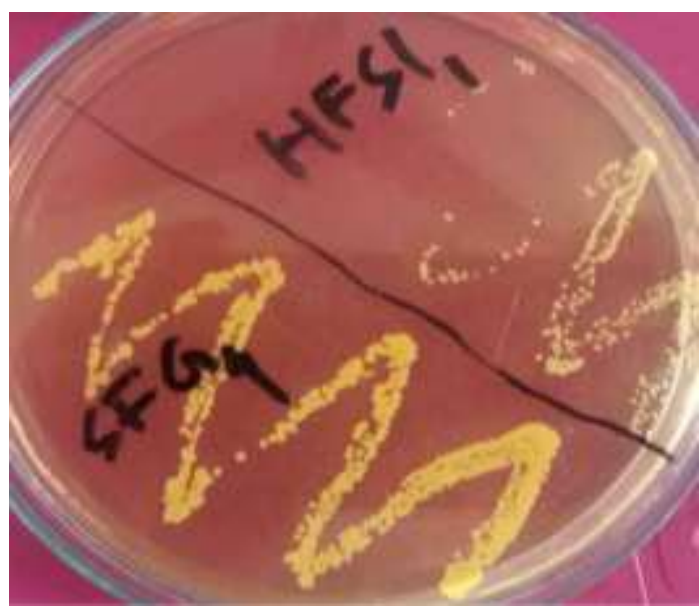

Fig.9 Colony of S. iniae on plate culture 


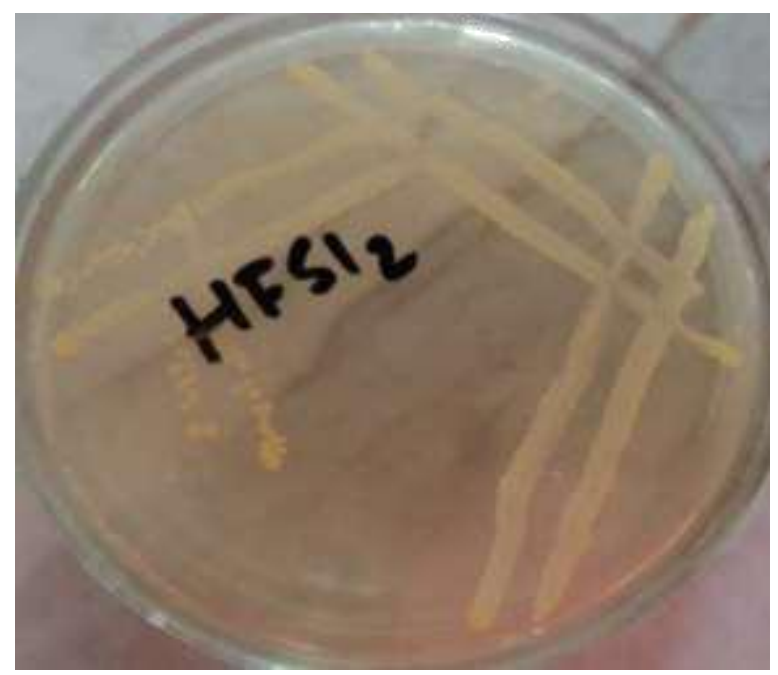

Fig.10 Colony of A. salmonicida on plate culture

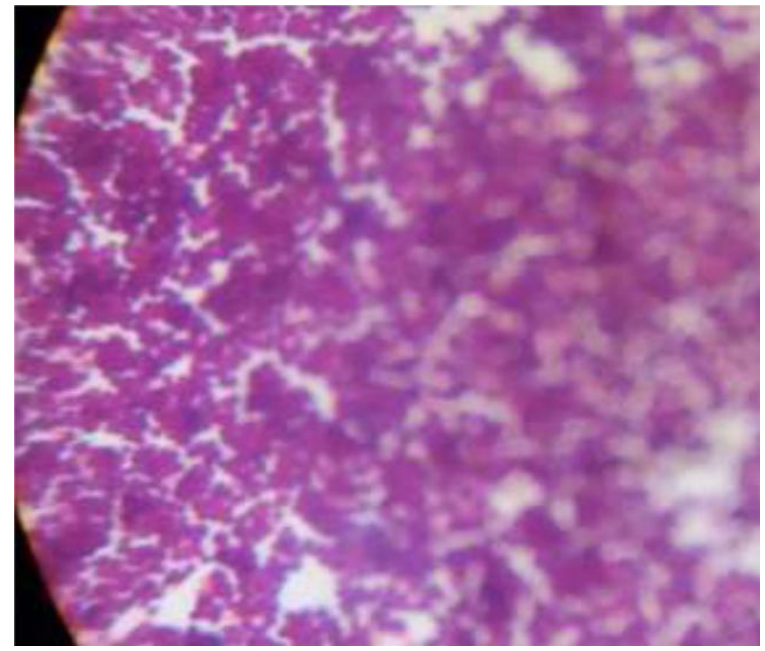

Fig.11 Gram positive S. Iniae

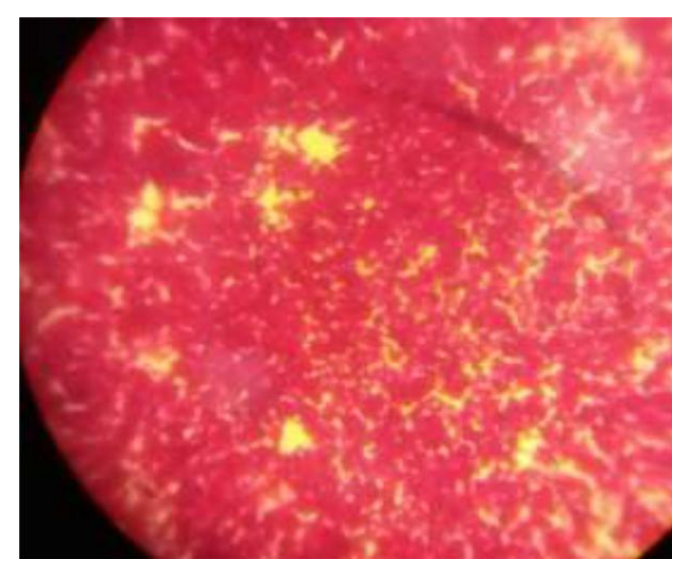

Fig.13 Gram negative E. tarda

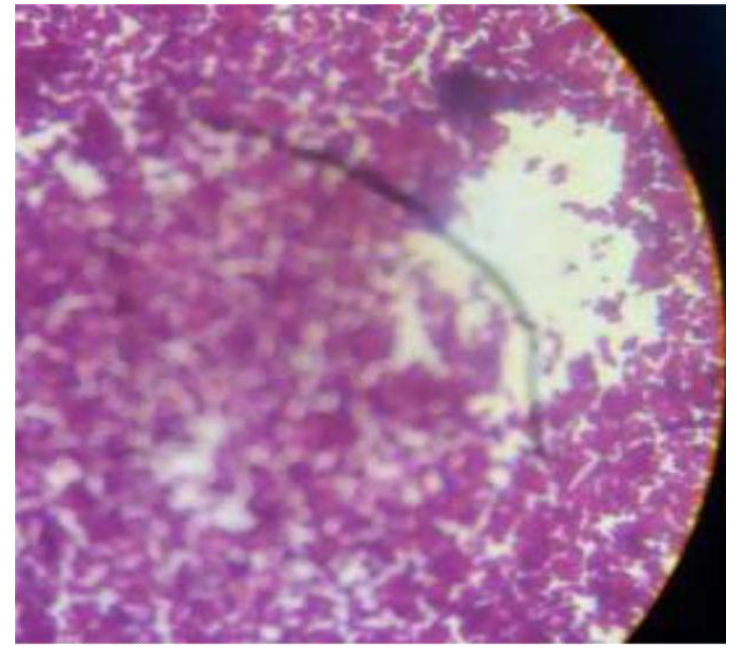

Fig.12 Gram positive $S$. agalactiae

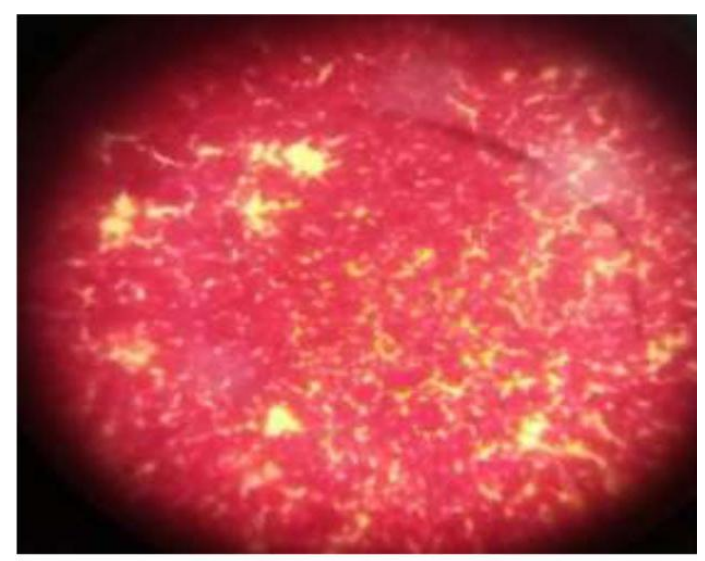

Fig.14 Gram negative F. columnare 


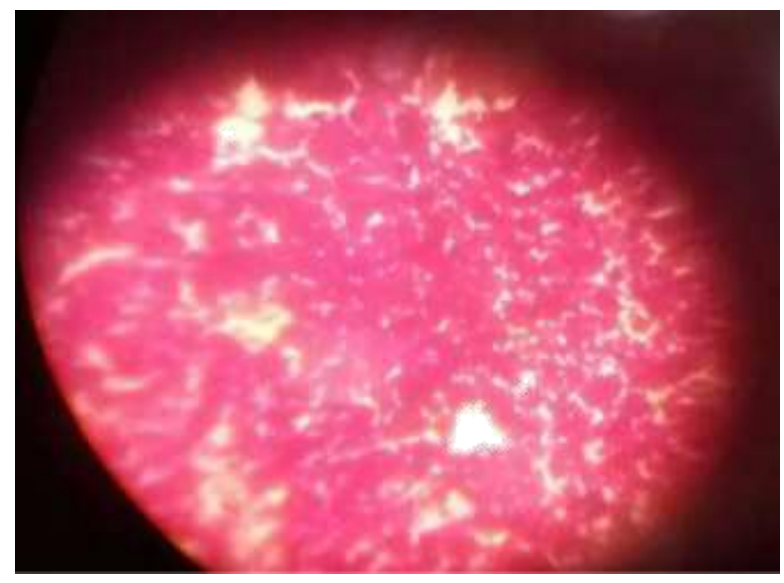

Fig.15 Gram negative A. Salmonicida

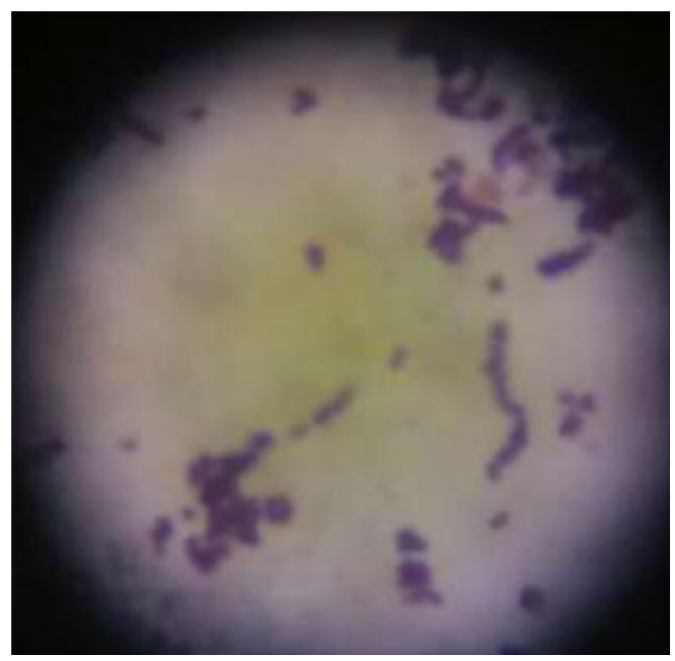

Fig.16 Motile Flavobacterium columnare

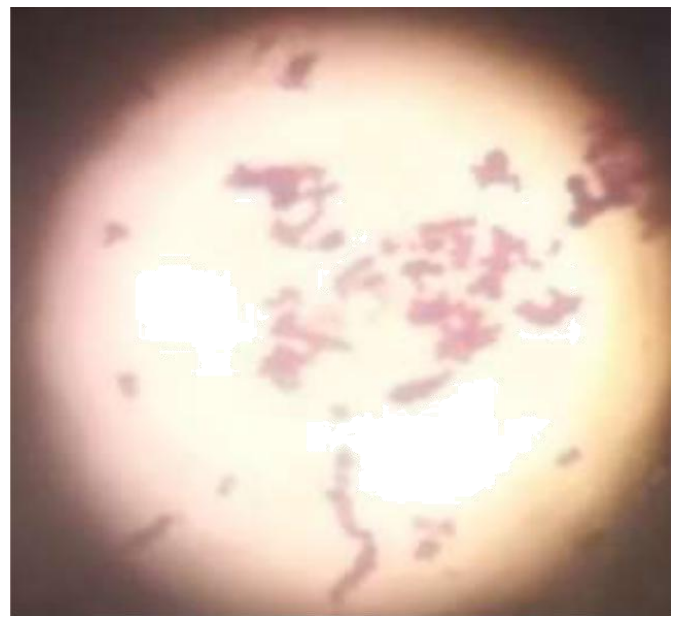

Fig.18 Non- motile A. salmonicida

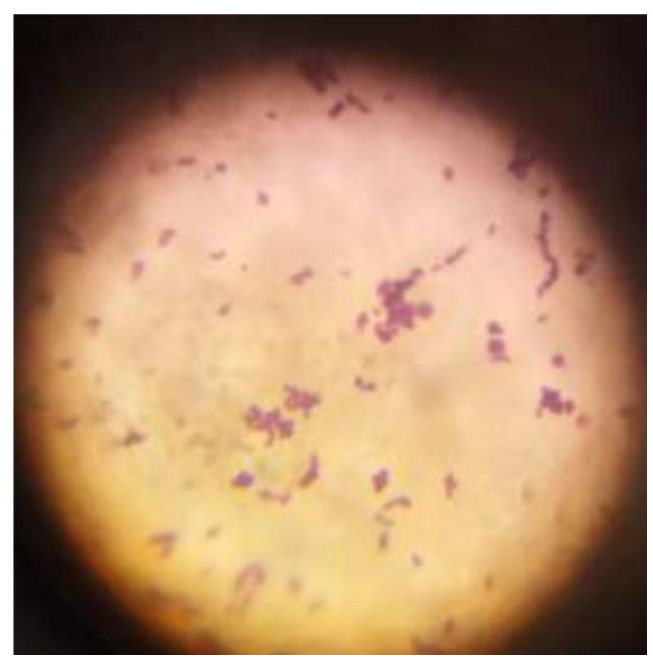

Fig.17 Motile Edwardsiella tarda

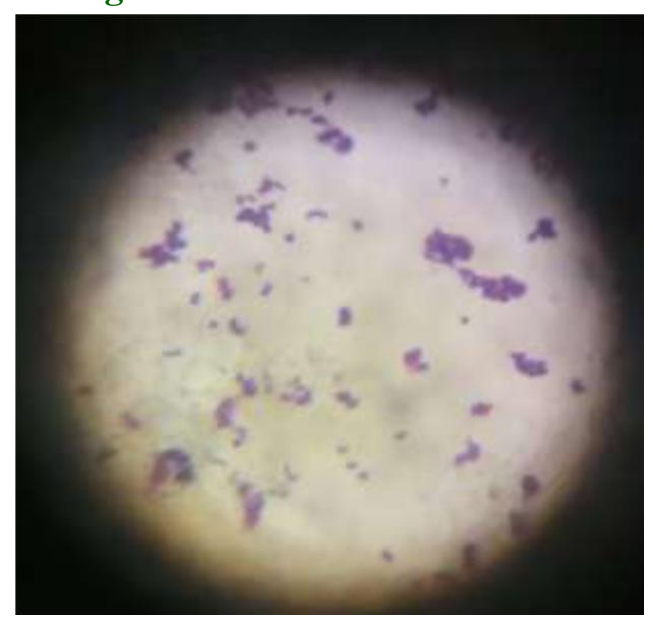

Fig.19 Non-motile S. iniae 


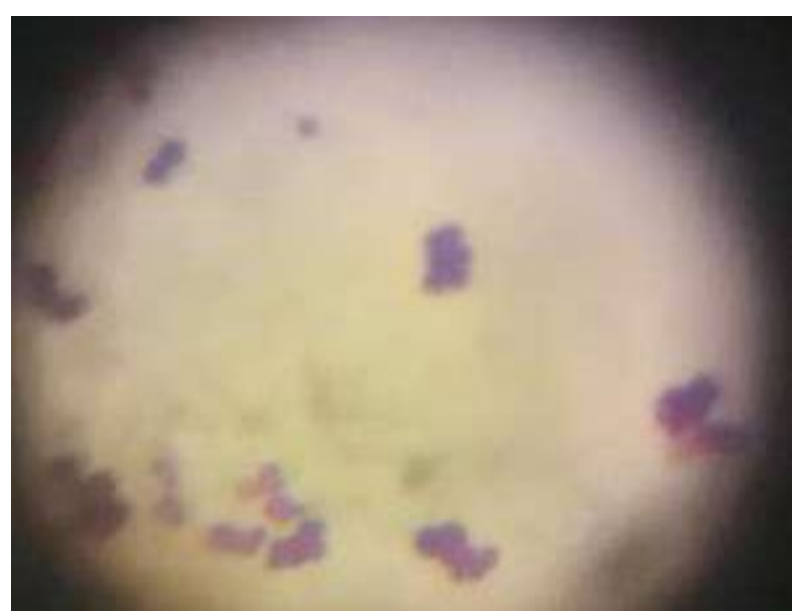

Fig.20 Non-motile $S$. agalactiae

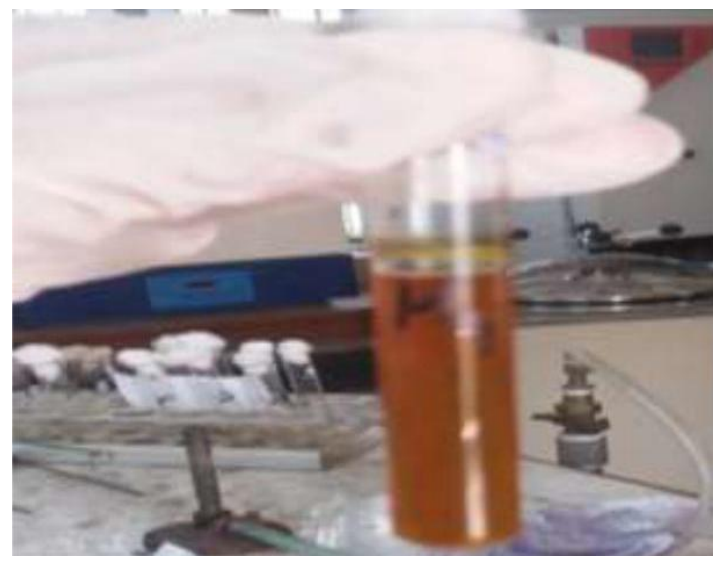

Fig.21 S. iniae showing positive in glucose,

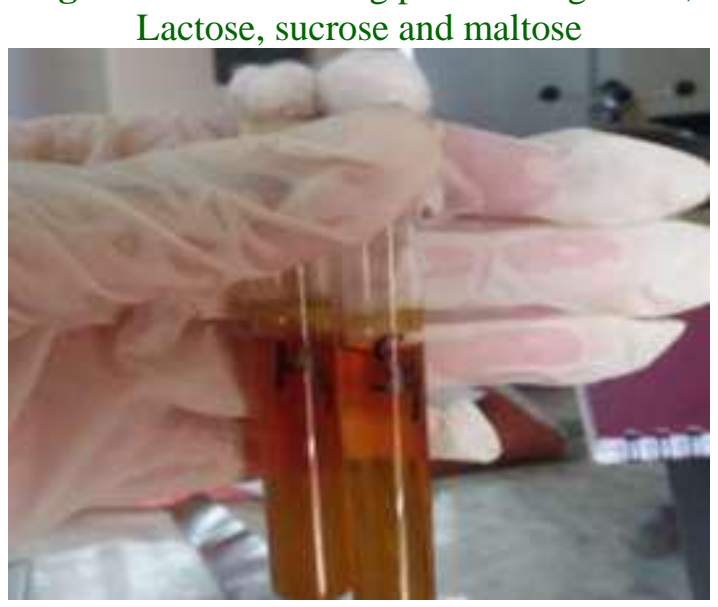

Fig.23 S. agalactiae showing positive in glucose, sucrose and maltose

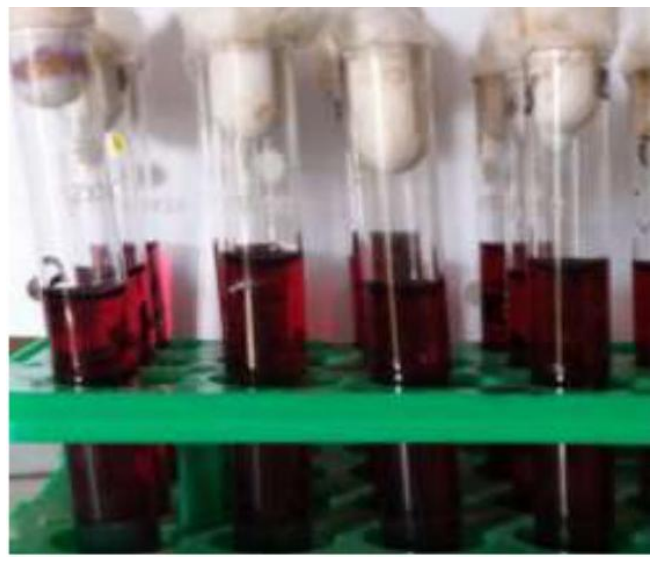

Fig.22 S. iniae showing negative in mannitol

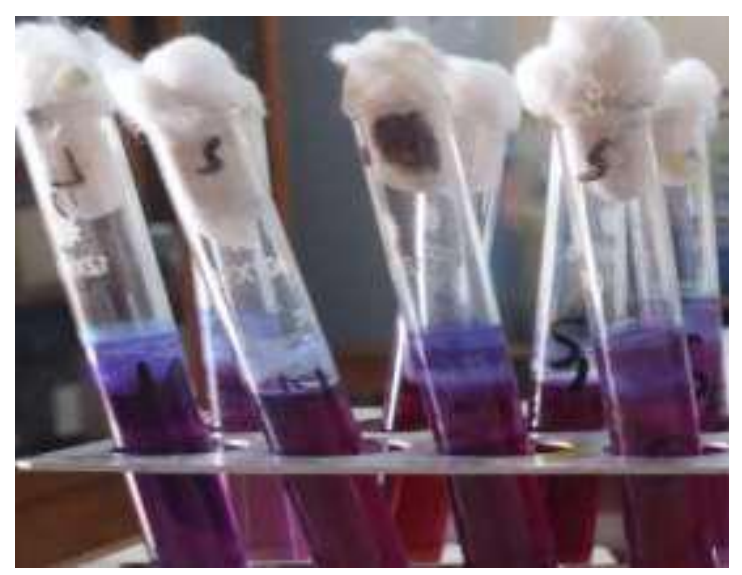

Fig.24 S. agalactiae showing negative in mannitol 


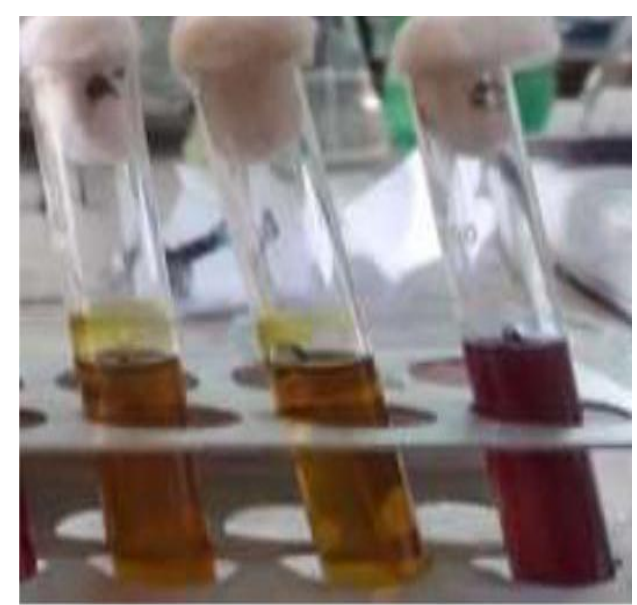

Fig.25 E. tarda showing positive in glucose and maltose

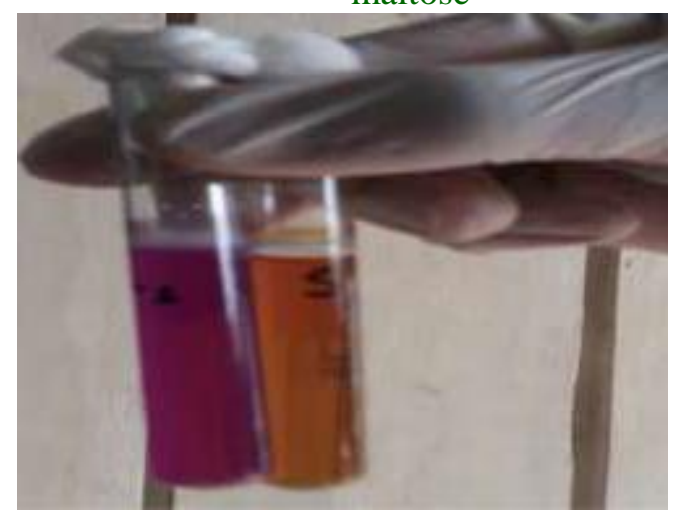

Fig.27 F. columnare showing acid production in lactose and sucrose, and negative results in glucose, maltose, mannitol

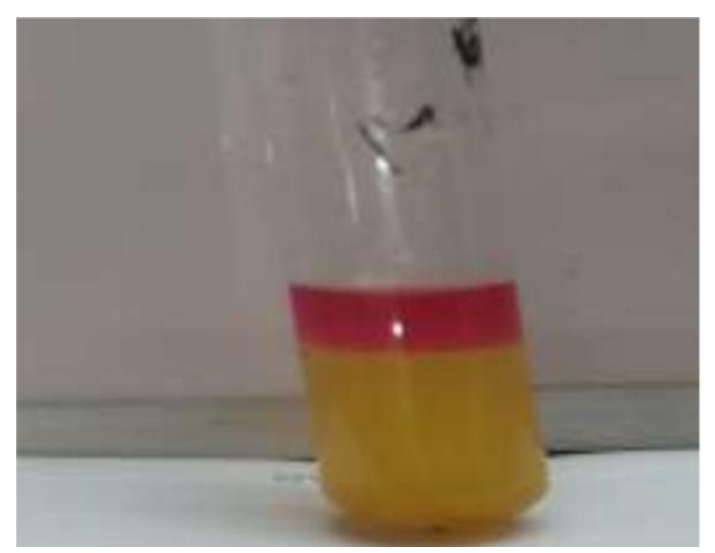

Fig.29 Both $S$. iniae and S. agalactiae showing positive indole test

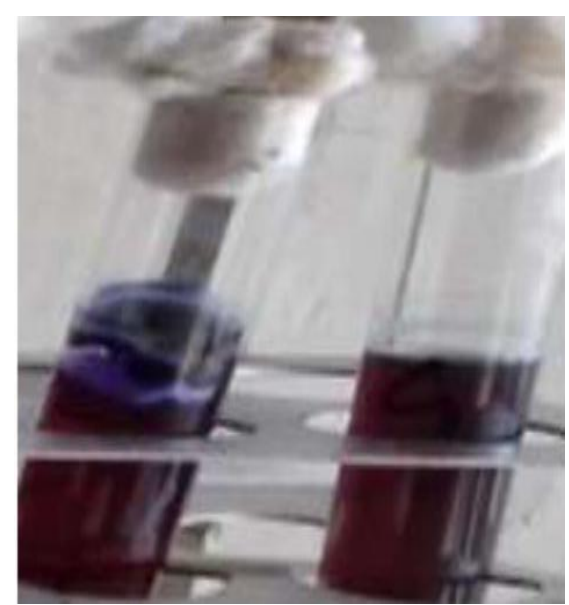

Fig.26 E. tarda showing negative in lactose, sucrose and mannitol

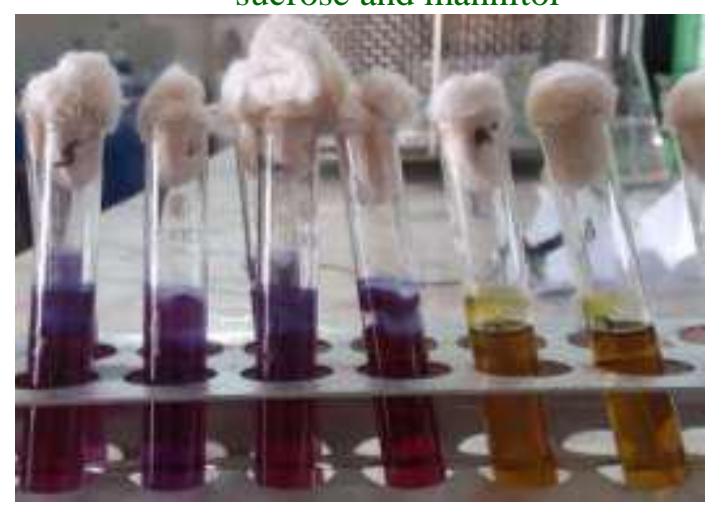

Fig.28 A. salmonicida showing positive in lactose, glucose, maltose, mannitol and negative in sucrose

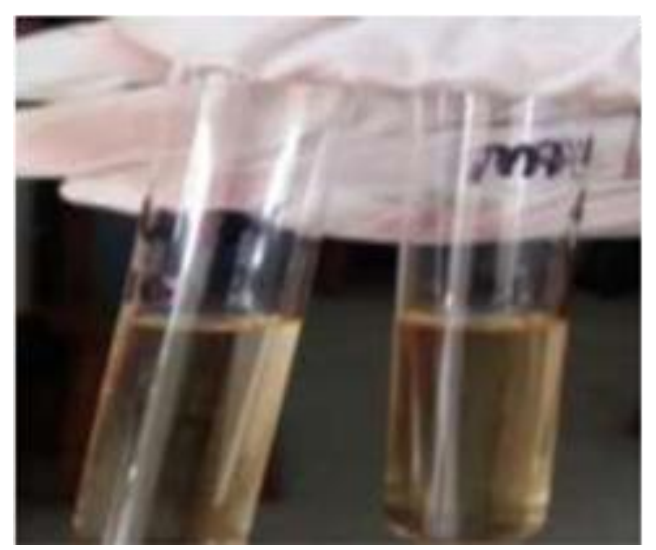

Fig.30 Both S. iniae and S. agalactiae showing negative MR test 


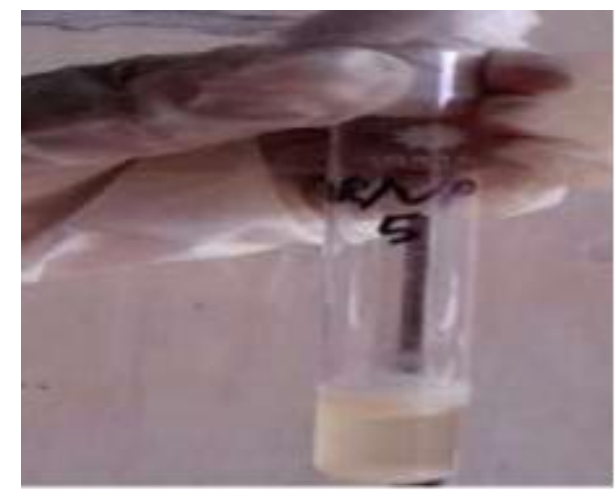

Fig.31 Only S. iniae showing negative VP test

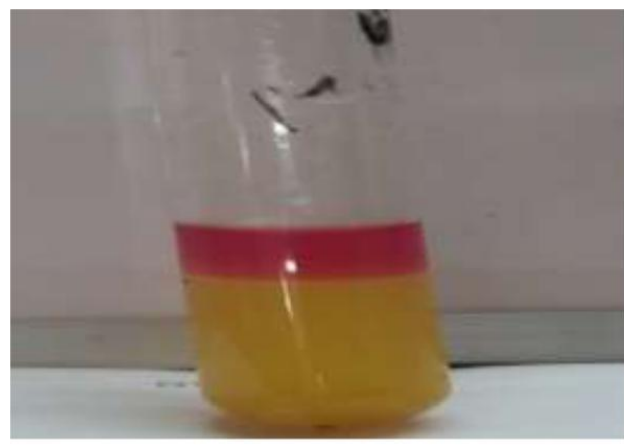

Fig.32 E. tarda showing positive indole test

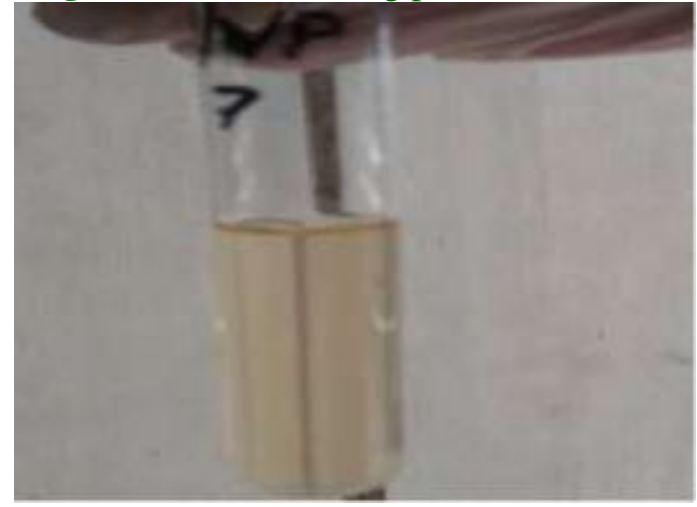

Fig.34 E. tarda showing positive

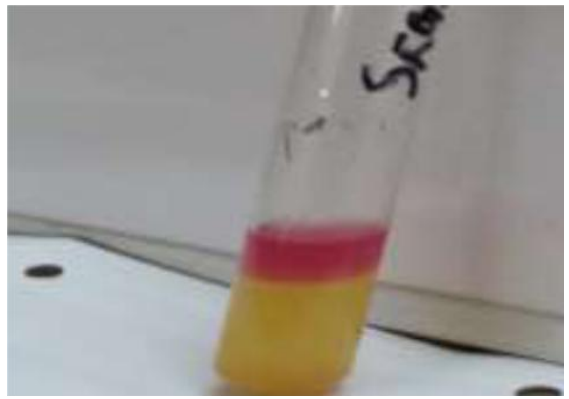

Fig.36 F . columnare showing positive indole test

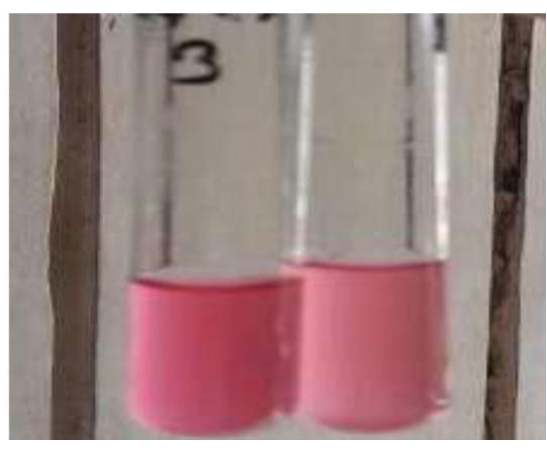

Fig.33 E. tarda showing positive MR test

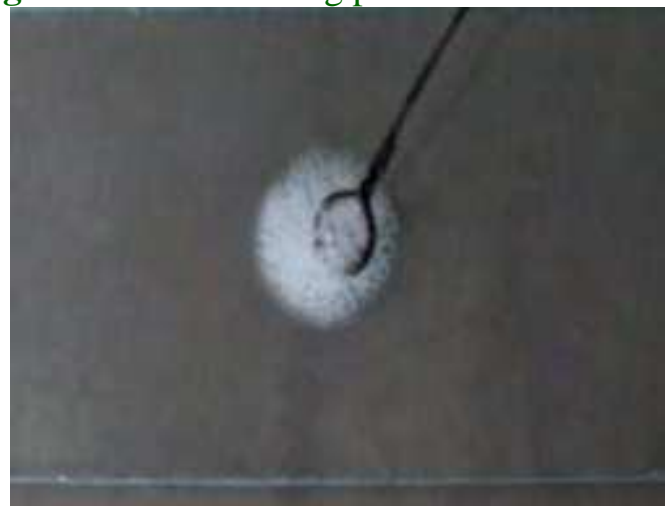

Fig.35 E. tarda showing negative VP test catalase test

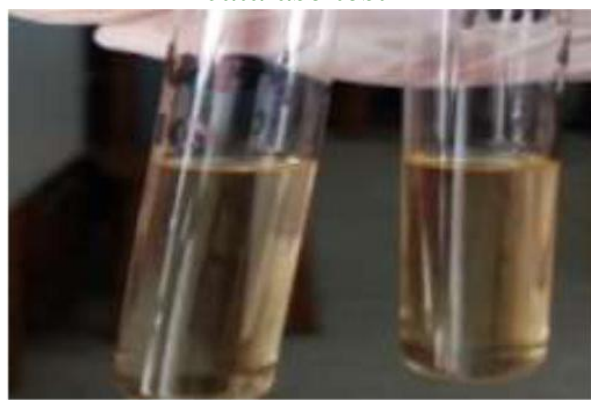

Fig.37 F. columnare showing negative MR test 


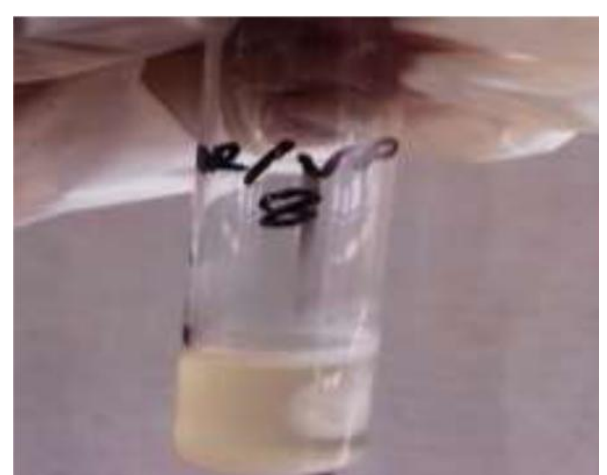

Fig.38 F. columnare showing negative VP test

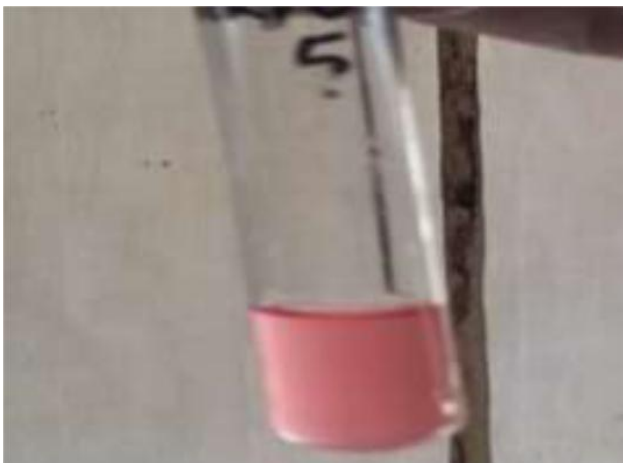

Fig.40 A. salmonicida showing positive MR test

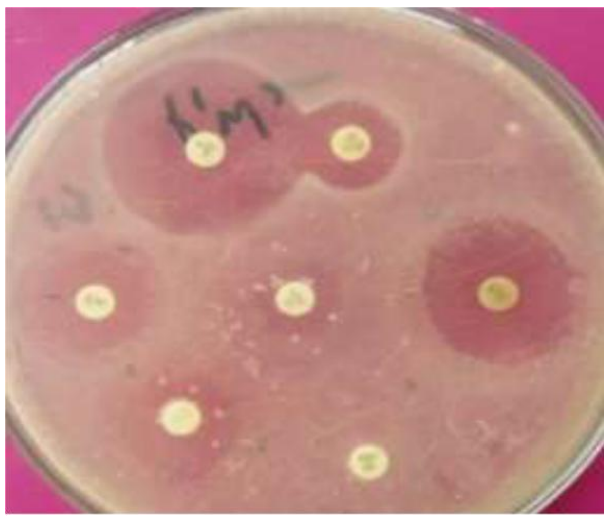

Fig.42 Antibiotic sensitivity of S. iniae

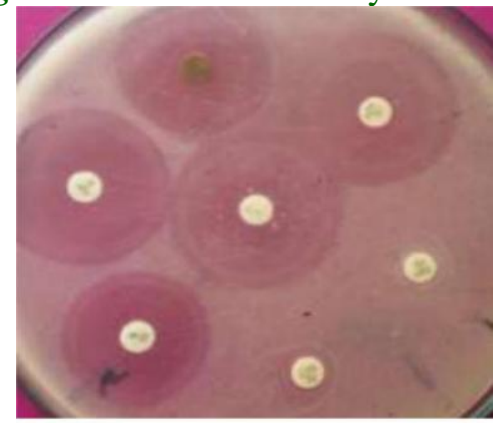

Fig.44 Antibiotic sensitivity of E. tarda

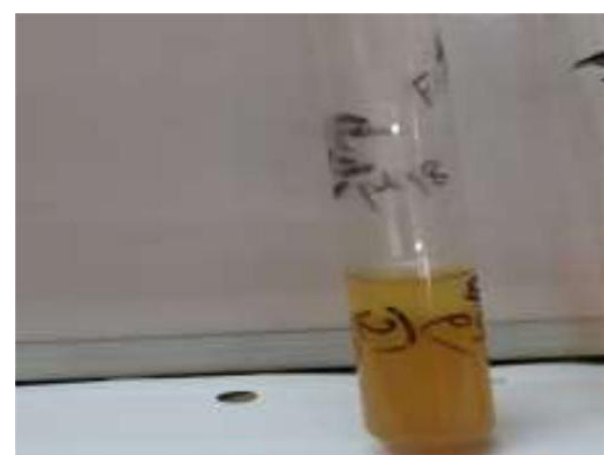

Fig.39 A. salmonicida showing negative indole test

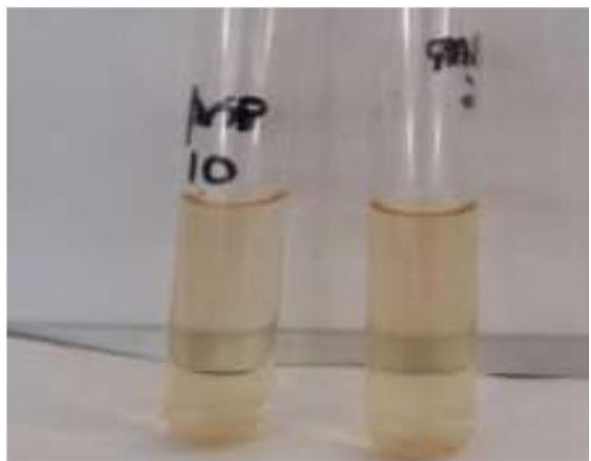

Fig.41 A. salmonicida showing negative VP test

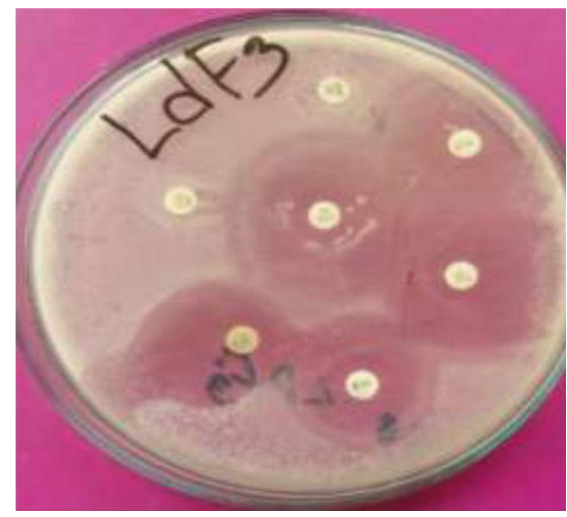

Fig.43 Antibiotic sensitivity of S.agalactiae

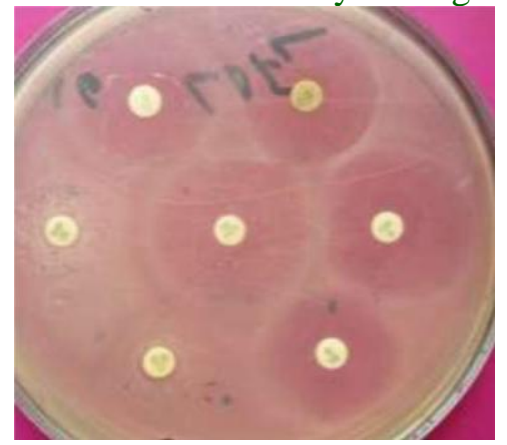

Fig.45 Antibiotic sensitivity of F.columnare 


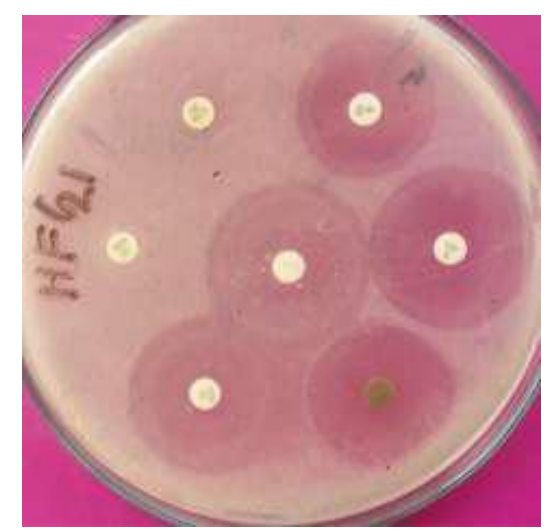

Fig.46 Antibiotic sensitivity of A. salmonicida

To conclude, tilapia has become the shining star of aquaculture with farm starting and expanding across the globe while consumption races arises. Tilapia holds a somewhat unique position amongst the major aquaculture fishes as a key product in international trade and have unique mouthbrooding form of reproduction and extreme hardiness. Occurrence of diseases is due mainly to several factors that act individually or jointly in an aquaculture, therefore, it is considered necessary the implementation of strategies for its optimal management, with the objective of achieving a sustainable production under safety and good management practices programs.

Having also the support of friendly treatments for fishes, in order to avoid direct and indirect losses, and to assure the production and success of $O$. niloticus. Colony characters and the biochemical analysis revealed the presence of $S$. agalactiae, $F$. columnare and E. tarda in farmed diseased tilapia, and $A$. salmonicida and $S$. iniae in healthy tilapia. Based on the density of colonies and clinical signs, the studied tilapia was infected by $S$. agalactiae, causing Streptococcosis.

Co-infections in tilapia were occurred by $F$. columnare and E. tarda. The effective antibiotics for all of the bacteria are Ciprofloxacin and Tetracycline. Thus, the disease of the studied tilapia could be controlled by using Ciprofloxacin or Tetracycline. The information of the study will be helpful for the management of bacterial diseases in Tilapia.

\section{Acknowledgement}

The authors are grateful to "PCR and histopathology based diagnosis and optimization of dosage of aqua-drugs to control diseases in Tilapia and Thai Pangas" project of Sylhet Agricultural University Research System (SAURES), Sylhet and "Optimization of dosage of aqua drugs and chemicals to control fish diseases through proper diagnosis using plate culture, histopathology and PCR techniques" project of Ministry of Science and Technology, Bangladesh for the financial support during the study.

\section{References}

Adebayo-Tayo, A.C., Odu, N.N., Michael, M.U. and Okonko, I.O. (2012). Multidrug resistant (MDR) organisms isolated from sea-foods in Uyo, southsouthern Nigeria. Nature and science, 10(3), 61-70.

Akinbowale, O.L., Peng, H. and Barton, M.D. (2006) Antimicrobial resistance in bacteria isolate from aquaculture sources in Australia. Journal of Applied Microbiology, 100(5), 1103-1113. 
Al- Harbi, A.H. and Uddin, N. (2003) Quantitative and qualitative studies on bacterial flora of hybrid tilapia (Oreochromis niloticus $\times$ O. aureus) cultured in earthen ponds in Saudi Arabia. Aquaculture Research, 34(1), 43-48.

Amal, M.N.A. and Zamri, S.M. (2011) Streptococcosis in tilapia (Oreochromis niloticus) a review. Pertanika Journal of Tropical Agricultural Science, 34(2), 195-206.

Anshary, H., Kurniawan, R.A., Sriwulan, S., Ramli, R. and Baxa, D.V. (2014). Isolation and molecular identification of the etiological agents of streptococcosis in Nile tilapia (Oreochromis niloticus) cultured in net cages in Lake Sentani Papua Indonesia. Springer Plus, 3, 627 (2014).

Asencios, Y.O., Sánchez, F.B., Mendizábal, H.B., Pusari, K.H., Alfonso, H.O., Sayán, A.M., Figueiredo, M.A.P., Manrique, W.G., de Andrade Belo, M.A. and Chaupe, N.S. (2016) First report of Streptococcus agalactiae isolated from $O$. niloticus in Piura, Peru. Molecular identification and histopathological lesions. Aquaculture reports, 2016, 74-79.

Ashiru, A.W., Uaboi-Egbeni, P.O., Oguntowo, J.E. and Idika, C.N. (2011). Isolation and antibiotic profile of Aeromonas species from Tilapia fish (Tilapia nilotica) and Catfish (Clarias batrachus). Pakistan journal of Nutrition, 10(10), 982-986.

Austin, B., Austin, D.A., Austin, B. and Austin, D.A. (2012). Bacterial fish pathogens. Heidelberg Springer. pp. 652.

Bolarinwa, A.O., Musefiu, T.A. and Obuko, E.B. (2011). The antibiotic resistant patterns of bacterial flora of fish from different aquatic environments from Ibadan, South-west Nigeria. Advances in Environmental Biology, 5(8), 20392047.

Borty, S.C., Rahman, F., Reza, A.A., Khatun, M.S., Kabir, M.L., Rahman, M.H. and Monir, M.S. (2016). Isolation, molecular identification and antibiotic susceptibility profile of Aeromonas hydrophila from cultured indigenous Koi (Anabus testudineus) of Bangladesh. Asian Journal of Medical and Biological Research, 2(2), 332-340.

Burr, S.E., Goldschmidt, Clermont, E., Kuhnert, P. and Frey, J. (2012). Heterogeneity of Aeromonas populations in wild and farmed perch Perca fluviatilis L. Journal of fish diseases 35(8), 607-613.

Dash, S.K., Chakraborty, S.P., Mandal, D. and Roy, S. (2012) Isolation and characterization of multi drug resistant uropathogenic Escherichia coli from urine sample of Urinary tract infected patients.

International Journal of Pharmaceutical and Life Science, 2, 25-39.

Dodson, S.V., Maurer, J.J. and Shotts, E.B. (1999). Biochemical and molecular typing of Streptococcus iniae isolated from fish and human cases. Journal of Fish Diseases, 22(5), 331-336.

DoF. (2018). National Fish Week 2018 Compendium (in Bengali) Department of Fisheries Bangladesh 160p.

FAO. (2018). The State of World Fisheries and Aquaculture2018-Meeting the sustainable development goals Rome. Licence CC BY-NC-SA 3.0 IGO

FRSS. (2017). Fisheries Statistical Report of Bangladesh. Fisheries Resources Survey System (FRSS) Department of Fisheries Bangladesh Volume (32) 57 p.

Giordano, L.G.P., Müller, E.E., Freitas, J.C.D. and Silva, V.G.D. (2010) Evaluation on the Pathogenesis of Streptococcus agalactiae in Nile Tilapia (Oreochromis niloticus). Brazilian 
Archives of Biology and Technology, 53(1), 87-92.

Goni, O., Alam, M.M.M., Khalil, S.M.I., Bari, S.M., Hamom, A., Parven, M. and Mamun, M.A.A. (2020). Identification of pathogenic bacteria from diseased stringing catfish Heteropneustis fossilis with their sensitivity to antibiotics. Journal of Fisheries and Aquatic Studies, 8(1), 291-301.

Khan, A.W., Hossain, S.J. and Uddin, S.N. (2007). Isolation, identification and determination of antibiotic susceptibility of Vibrio parahaemolyticus from shrimp at Khulna region of Bangladesh. Research Journal of Microbiology, 2, 216-227.

Klesius, P., Evans, Shoemaker, C., Yeh, H.Y., Goodwin, A.E., Adams, A. and Thompson, K. (2008) Rapid detection and identification of Streptococcus iniae using a monoclonal antibody-based indirect fluroscent antibody technique. Aquaculture, 258(1-4), 180-186.

Monir, M.S., Bagum, N., Kabir, S.M.L., Borty, S.C. and Ud-Doulah, M.A. (2017). Isolation molecular identification and characterization of Aeromonas hydrophila from infected air-breathing catfish Magur (Clarias batrachus) cultured in Mymensingh, Bangladesh. Asian-Australasian journal of food safety and security, 1(1), 17-24.

Nilla, S.S., Mustafa, M.G., Khan, M.M., Khan. (2014). Microbial quality assessment of Indian white shrimp, Penaeus indicus from southwest Bangladesh. In Abstracts book of 5th Fisheries Conferences and Research Fair (p. 179).

Parven, M. (2018). Diagnosis of bacterial pathogens in diseased Pangasius hypophthalmus and evaluation of their sensitivity to antibiotics. MS Thesis, Department of Fish Health Management, Sylhet Agricultural
University, Sylhet, Bangladesh.

Perera, R.P., Johnson, S.K., Collins, M.D., Lewis, D.H. (1994). Streptococcus iniae associated with mortality of Tilapia nilotica $\times \mathrm{T}$. aurea hybrids. Journal of Aquatic Animal Health, 6(4), 335-340.

Sabur, M.A. (2006). Studies on the ecology of the pathogenic bacteria Aeromonas hydrophila in indigenous and exotic carps under polyculture condition. PhD Thesis. Department of Aquaculture, Bangladesh Agricultural University, Mymensingh, Bangladesh.

Saeed, M.A. (2010) Isolation and identification of Aeromonas hydrophila bacteria from indigenous koi (Anabus testudineus). M.S. Thesis, Department of Aquaculture, Bangladesh Agricultural University, Mymensingh, Bangladesh.

Saikot, F.K., Zaman, R. and Khalequzzaman, M. (2013) Pathogenecity test of Aeromonas isolated from motile Aeromonas septicemia (MAS) infected Nile Tilapia on some freshwater fish. Science International, 325-329.

Sankar, G., Saravanan, J., Krishnamurthy, P., Chandrakala, N. and Rajendran, K. (2012). Isolation and identification of Vibrio spp in diseased Channa punctatus from aquaculture fish farm. Indian Journal of Geo-Marine Science, 41(2), 159-163.

Sarker, M.G., Chowdhury, M.B.R., Faruk, M.N. and Islam, M.J. (2000) Effect of water temperature on the infectivity of Aeromonas hydrophila isolates. Bangladesh Journal Fisheries, (23), 99105.

Soto, S.A. (2009) Water quality and bacteria present in cultivated tilapia. Foundation produces Tilapia AC pp 7-19.

Sugita, H., Tokuyama, K. and Deguchi, Y. 1985: The intestinal microflora of carp Cyprinus carpio, grass carp Ctenopharyngodon idella and tilapia 
Sarotherodon niloticus. Bulletin of the Japanese Society

Scientific Fisheries, 51(8), 1325-9.

Tiamiyu, A.M., Soladoye, M.O., Adegboyega, T.T. and Adetona, M.O. (2015). Occurrence and antibiotic sensitivity of bacterial strains isolated from Nile Tilapia, Oreochromis niloticus obtained in Ibadan, Southwest
Nigeria. Journal of Biosciences and Medicines, 3(05), 19-26.

Yardimci, B. and Aydin, Y. (2011). Pathological findings of experimental Aeromonas hydrophila infection in Nile tilapia (Oreochromis niloticus). Ankara Universitesi Veteriner Fakultesi Dergisi, 58, 47-54.

\section{How to cite this article:}

Aishi Hamom, M. M. Mahbub Alam, Mohammed Mahbub Iqbal, Sarker Mohammed Ibrahim Khalil, Moslima Parven, Tofael Ahmed Sumon and Md. Abdullah-Al-Mamun. 2020. Identification of Pathogenic Bacteria from Diseased Nile Tilapia Oreochromis niloticus with their Sensitivity to Antibiotics. Int.J.Curr.Microbiol.App.Sci. 9(03): 1716-1738.

doi: https://doi.org/10.20546/ijcmas.2020.903.200 